\title{
Potential macro-detritivore range expansion into the subarctic stimulates litter decomposition: a new positive feedback mechanism to climate change?
}

\author{
Koert G. van Geffen • Matty P. Berg $\cdot$ Rien Aerts
}

Received: 18 October 2010/ Accepted: 6 June 2011/Published online: 7 July 2011

(c) The Author(s) 2011. This article is published with open access at Springerlink.com

\begin{abstract}
As a result of low decomposition rates, highlatitude ecosystems store large amounts of carbon. Litter decomposition in these ecosystems is constrained by harsh abiotic conditions, but also by the absence of macro-detritivores. We have studied the potential effects of their climate change-driven northward range expansion on the decomposition of two contrasting subarctic litter types. Litter of Alnus incana and Betula pubescens was incubated in microcosms together with monocultures and all possible combinations of three functionally different macro-detritivores (the earthworm Lumbricus rubellus, isopod Oniscus asellus, and millipede Julus scandinavius). Our results show that these macro-detritivores stimulated decomposition, especially of the high-quality A. incana litter and that the macro-detritivores tested differed in their decomposition-stimulating effects, with earthworms having the
\end{abstract}

Communicated by Stephan Hättenschwiler.

Electronic supplementary material The online version of this article (doi:10.1007/s00442-011-2051-8) contains supplementary material, which is available to authorized users.

K. G. van Geffen · R. Aerts $(\bowtie)$

Department of Systems Ecology, Institute of Ecological Science,

VU University, De Boelelaan 1085, 1081 HV Amsterdam,

The Netherlands

e-mail: Rien.aerts@ecology.falw.vu.nl

\section{P. Berg}

Department of Animal Ecology, Institute of Ecological Science,

VU University, De Boelelaan 1085, 1081 HV Amsterdam,

The Netherlands

Present Address:

K. G. van Geffen

Nature Conservation and Plant Ecology group, Wageningen

University and Research Centre, Droevendaalsesteeg 3a,

P.O. Box 47, 6700 AA Wageningen, The Netherlands largest influence. Decomposition processes increased with increasing number of macro-detritivore species, and positive net diveristy effects occurred in several macro-detritivore treatments. However, after correction for macrodetritivore biomass, all interspecific differences in macrodetritivore effects, as well as the positive effects of species number on subarctic litter decomposition disappeared. The net diversity effects also appeared to be driven by variation in biomass, with a possible exception of net diversity effects in mass loss. Based on these results, we conclude that the expected climate change-induced range expansion of macro-detritivores into subarctic regions is likely to result in accelerated decomposition rates. Our results also indicate that the magnitude of macro-detritivore effects on subarctic decomposition will mainly depend on macrodetritivore biomass, rather than on macro-detritivore species number or identity.

Keywords Climate change - Feedback mechanism . Litter decomposition - Macro-detritivores · Net diversity effects

\section{Introduction}

In high-latitude ecosystems, less biospheric carbon is respired into the atmosphere via decomposition than is gained by photosynthesis, making these ecosystems large sinks of atmospheric carbon (Jonasson et al. 2001). Decomposition rates in these ecosystems are generally constrained by low temperatures, water-logging, anoxic and acidic site conditions, low nutrient concentrations in plant litter, and/or high concentrations of secondary compounds, such as lignin and phenolics (Robinson 2002). However, given the temperature sensitivity of decomposition, 
especially at low temperatures (Fierer et al. 2005), combined with the high velocity of climatic warming predicted at high latitudes (IPCC 2007), decomposition rates are expected to increase in the future (Aerts 2006). The consequences of altered decomposition rates at high latitudes can be enormous. For example, if decomposition rates increase, the large soil carbon stocks of high-latitude ecosystems are at risk, which might result in increased carbon dioxide $\left(\mathrm{CO}_{2}\right)$ fluxes to the atmosphere, thereby creating a positive feedback to climate warming (Dorrepaal et al. 2009).

In addition to the abiotic constraints on high-latitude decomposition, the general absence of macro-detritivores, such as earthworms, millipedes, and isopods, which is a characteristic of high-latitude soils (Ruess et al. 1999), might also contribute to the low decomposition rates (Aerts 2006; Rouifed et al. 2010). After all, macro-detritivores are often shown to increase litter mass loss rates (Scheu and Parkinson 1994; Seatre 1998; Cárcamo et al 2000; Hättenschwiler and Bretscher 2001; Heemsbergen et al. 2004). This positive macro-detritivore effect on decomposition is particularly pronounced in litter of relatively poor quality (Tian et al. 1995; Cárcamo et al. 2000) and is a result of direct litter consumption and assimilation by macro-detritivores (Hassall et al. 1987), as well as indirect macro-detritivore effects, such as mixing soil and litter layers and litter fragmentation, both of which stimulate microbial decomposition (Hopkin and Read 1992; Trajovský et al. 1992; Wardle and Lavelle 1997).

Although of potentially great importance for high-latitude decomposition rates, the indirect effect of climate change on decomposition via shifts in decomposer community composition (Aerts 2006) has received little attention to date (Briones et al. 2007). It is broadly recognized that species' ranges in the northern hemisphere are shifting northward in response to warming (Parmesan and Yohe 2003; Root et al. 2003; Berg et al. 2010). These patterns are also apparent in macro-detritivores: Hickling et al. (2006) showed that the northern range margin of eight species of woodlice and six species of millipedes in the UK showed average poleward shifts of 79 and $74 \mathrm{~km}$, respectively, over the past 25 years. Although a causal relationship of such range expansions with climate change cannot easily be assumed (David and Handa 2010), positive temperature effects on macro-detritivore life-histories and population characteristics indicate that the physiological basis required for climate change-induced northward range expansion is present in macro-detritivores (David and Gillon 2009; David and Handa 2010), making climate change-induced range expansions very likely. Several other studies have also underlined the possibility of climate change-mediated northward range expansions of macro-detritivores (Hodkinson and Wookey 1999; Coûteaux and Bolger 2000; Bohlen et al. 2004; Berg et al. 2010). This northward range expansion of macro-detritivores potentially leads to increased decomposition rates in previously macro-detritivore-free areas (Bohlen et al. 2004), with accompanying alterations in high-latitude carbon budgets.

The velocity of climate change-mediated range expansions, either by active or passive movement, will differ between species and functional groups of macro-detritivores, which makes it essential to study the influence of single species in the decomposition process. Relatively little is currently known about the role of macro-detritivore identity and macro-detritivore interactions in ecosystem processes (Gessner et al. 2010). Only a few recent studies have focussed on the importance of macro-detritivore identity effects on terrestrial ecosystem processes, such as decomposition (Heemsbergen et al. 2004; Zimmer et al. 2005; De Oliveira et al. 2010; Hedde et al. 2010; Vos et al. 2011), and the results of these studies indicate that different macro-detritivores can have functionally different effects on litter decomposition (Heemsbergen et al. 2004). For example, isopods and millipedes are litter-fragmenting animals, whereas earthworms in general fragment litter to a lesser extent, but mix litter and soil layers instead. Interactions between functionally different macro-detritivores can lead to non-additive effects (net diversity effects, NDEs) on ecosystem processes, such as decompositioni.e., the observed effect of a mixture of macro-detritivore species differs from what would be expected based on single macro-detritivore effects (Heemsbergen et al. 2004). Hence, interspecific macro-detritivore interactions may be an important determinant of the potential macro-detritivore effect on decomposition in high-latitude regions where these macro-detritivores have been absent so far.

Despite the recognition that macro-detritivores potentially increase future high-latitude decomposition rates, this effect has never before been quantified. The primary aim of the study reported here was, therefore, to investigate the potential influence of macro-detritivores on litter decomposition processes in a subarctic ecosystem where this soil fauna group is currently absent. We also investigated the importance of macro-detritivore identity and interspecific interactions on subarctic decomposition processes. To this end, we studied the decomposition processes (litter mass loss, respiration, and fragmentation) of two contrasting species of subarctic leaf litter in microcosms under laboratory-controlled subarctic environmental conditions. These litters were subjected to three functionally different macro-detritivores (and all combinations thereof) whose current ranges are bordering subarctic regions. We hypothesized that (1) macro-detritivores will positively influence decomposition rates of subarctic leaf litter, particularly in relatively poor quality litter; (2) this decomposition effect will depend on macro-detritivore identity, so that decomposition-stimulating effects will differ between 
earthworms, millipedes, and isopods; (3) interspecific interactions between macro-detritivores will result in net diversity effects, particularly when functionally different species (i.e., earthworm and millipede, earthworm and isopod) are combined.

\section{Materials and methods}

Litter and animal collection

We studied the decomposition effect of macro-detritivores on two contrasting litter types: Betula pubescens spp. czerepanovii (Ehrh.) [carbon:nitrogen (C:N) ratio 49.9; phosphorus $(\mathrm{P})$ concentration $0.12 \%$; lignin concentration 27.1\%; moderately decomposable] and Alnus incana [(L.) Moench] (C:N ratio 18.1; $\mathrm{P}$ concentration $0.06 \%$; lignin concentration $21.8 \%$; easily decomposable). Fresh litter of these species was collected in September 2009 from a subarctic birch-dominated forest stand with a heath vegetation understory in Abisko, Swedish Lapland $\left(68^{\circ} 21^{\prime} \mathrm{N}\right.$, $\left.18^{\circ} 49^{\prime} \mathrm{E}\right)$. B. pubescens spp. czerepanovii is the dominant tree species in Abisko, whereas A. incana is a $\mathrm{N}$-fixing tree species, mainly found along the Abiskojåkka river.

Animals living on the border of their range can be adapted to local conditions (Thomas et al. 2001). Therefore, our aim was to collect animals from the northern border of their current ranges. We therefore hand-collected earthworms [Lumbricus rubellus (Hoffmeister, 1843)] in August and September 2009 in Abisko, where they are present in very low densities in the sheltered, heavily disturbed, deep soils of the experimental garden of the Abisko Research Station, but absent from the surrounding birch forests and marshes. Isopods [Onsicus asellus (Linneaeus, 1758)] and millipedes [Julus scandinavius (Latzel, 1884)] were hand-collected about $950 \mathrm{~km}$ to the south, in a mixed forest stand on an east-facing slope, approximately $3 \mathrm{~km}$ south of Uppsala, Sweden $\left(66^{\circ} 34^{\prime} \mathrm{N}, 16^{\circ} 04^{\prime} \mathrm{E}\right)$ in September 2009. All three macro-detritivore species also occur in more southern parts in Europe, up to the Mediterranean area. Hence, the Swedish populations are at the northernmost edge of the species' ranges. Animals were transported to the Netherlands in a cool box at approximately $10-15^{\circ} \mathrm{C}$ and stored at $14^{\circ} \mathrm{C}$ for 1 month prior to the start of the experiment.

\section{Experimental set-up}

Decomposition experiments were performed in a climate room at the VU University in Amsterdam that was kept at $12^{\circ} \mathrm{C}$ (mimicking subarctic summer temperatures, based on Abisko temperature datasets) and $50 \%$ relative humidity, under a light/dark regime of $10 / 14 \mathrm{~h}$, respectively. Open-top non-transparent polyethylene microcosms (diameter $12.5 \mathrm{~cm}$, depth $8.5 \mathrm{~cm}$ ) were used, of which the bottom consisted of microfiber mesh (mesh size $75 \mu \mathrm{m}$ ). Each microcosm was filled with $150 \mathrm{~g}$ (approx. $1 \mathrm{~cm}$ thick layer) of moist river sand (HS Aqua Maaszand, Smulders, The Netherlands). Dry litter of both species was sieved through 16- and 8-mm sieves. Prior to incubation, we rewetted 40 subsets of $10 \mathrm{~g}$ litter (dry weight after drying at $40^{\circ} \mathrm{C}$ ) of $A$. incana (equivalent to $6.99 \pm 0.30 \mathrm{~g}$ dry weight at $70^{\circ} \mathrm{C}$ ) and B. pubescens (equivalent to $7.84 \pm 0.36 \mathrm{~g}$ dry weight at $70^{\circ} \mathrm{C}$ ) by submerging the samples in water for $5 \mathrm{~h}$. We distributed two litter size classes ( $>16 \mathrm{~mm}$ and $16-8 \mathrm{~mm}$ ) equally across the subsets. Each rewetted subset was incubated in one microcosm.

We shook $1 \mathrm{~kg}$ of forest soil organic layer from the site where the litter had been collected in 21 of water for $1 \mathrm{~h}$ at $225 \mathrm{rpm}$, after which we sieved the solution through a $180-\mu \mathrm{m}$ sieve. The resulting extractant was sprayed (approx. $7 \mathrm{ml}$ ) over water-saturated litter prior to the start of the experiment in order to inoculate litter with subarctic soil fungi and bacteria. The layer of river sand in the microcosms was separated from the litter layer using a 1-mm-thick plastic mesh with $1-\mathrm{mm}^{2}$ holes, which allowed for microbial and moisture exchange between the sand and litter layer but prevented any mixing of soil and litter which would complicate re-collection of the litter. Microcosms were placed on an approximately 1-cm-thick moist layer of Plaster of Paris. After some episodes during the first week (see below) involving the escape of macro-detritivores, the microcosms were covered with nets (mesh size $0.2 \mathrm{~mm}$ ).

Macro-detritivore treatments included earthworm (E), millipede (M), and isopod (I) addition, and the combined additions of $\mathrm{E}+\mathrm{M}, \mathrm{E}+\mathrm{I}, \mathrm{M}+\mathrm{I}$, and $\mathrm{E}+\mathrm{M}+\mathrm{I}$. Animals were randomly assigned to treatments. We intended to keep macro-detritivore biomass approximately equal across our treatments (Table 1), but this was not always possible due to high earthworm biomass. We had two types of controls: one with no macro-detritivore addition to assess microbial decomposition only, and one to control for soil respiration in $\mathrm{CO}_{2}$ measurements (see below) containing only soil, no litter. During the course of the experiments, litter in the microcosms was rewetted three times per week using a water sprayer. Plaster of Paris was rewetted until saturation twice a week. The layer of river sand in the microcosms allowed for moisture exchange between the Plaster of Paris and the litter, thereby buffering any large variation in 'bottom-up' moisture and thus preventing water saturation of the litter. A randomized block design (Krebs 1999) was applied in which all treatments were replicated once within a block, and blocks were replicated five times. We weekly rotated the blocks within the climate 
Table 1 The amount $(n)$ and dry and fresh weight, respectively, of different macro-detritivores added to the different treatments

\begin{tabular}{|c|c|c|c|c|c|c|c|c|c|c|c|}
\hline \multirow[t]{2}{*}{ Treatment } & \multicolumn{3}{|c|}{$\begin{array}{l}\text { Lumbricus rubellus } \\
\text { (earthworm) }\end{array}$} & \multicolumn{3}{|c|}{$\begin{array}{l}\text { Julus scandinavius } \\
\text { (millipedes) }\end{array}$} & \multicolumn{3}{|c|}{ Onsicus asellus (isopods) } & \multicolumn{2}{|c|}{$\begin{array}{l}\text { Total macro-detritivore } \\
\text { biomass }\end{array}$} \\
\hline & $n$ & FW (g) & DW (g) & $n$ & FW (g) & DW (g) & $n$ & $\mathrm{FW}(\mathrm{g})$ & DW (g) & FW (g) & DW (g) \\
\hline $\mathrm{C}$ & 0 & & & 0 & & & 0 & & & & \\
\hline $\mathrm{E}$ & 2 & $1.63(0.169)$ & $0.32(0.04)$ & 0 & & & 0 & & & $1.63(0.169)$ & $0.32(0.04)$ \\
\hline M & 0 & & & 10 & $0.68(0.13)$ & $0.29(0.06)$ & 0 & & & $0.68(0.13)$ & $0.29(0.06)$ \\
\hline I & 0 & & & 0 & & & 10 & $0.89(0.15)$ & $0.31(0.05)$ & $0.89(0.15)$ & $0.31(0.05)$ \\
\hline$E+M$ & 1 & $0.85(0.15)$ & $0.17(0.03)$ & 10 & $0.67(0.18)$ & $0.29(0.07)$ & 0 & & & $1.52(0.31)$ & $0.46(0.10)$ \\
\hline $\mathrm{E}+\mathrm{I}$ & 1 & $0.79(0.31)$ & $0.16(0.06)$ & 0 & & & 10 & $0.87(0.11)$ & $0.30(0.04)$ & $1.66(0.34)$ & $0.46(0.08)$ \\
\hline$M+I$ & 0 & & & 5 & $0.34(0.07)$ & $0.15(0.03)$ & 5 & $0.43(0.08)$ & $0.15(0.03)$ & $0.77(0.12)$ & $0.29(0.05)$ \\
\hline$E+M+I$ & 1 & $0.84(0.32)$ & $0.17(0.06)$ & 5 & $0.35(0.10)$ & $0.15(0.05)$ & 5 & $0.47(0.08)$ & $0.16(0.03)$ & $1.66(0.35)$ & $0.48(0.08)$ \\
\hline
\end{tabular}

Data are presented as the average of five Alnus incana and five Betula pubescens replicates, with the standard deviation (SD) in parenthesis

C, control; E, earthworm; M, millipede; I, isopod). Macro-detritivore dry weight was based on dry weight:fresh weight (DW:FW) ratios of a random subset of 5 earthworms, 16 millipedes, and 15 isopods at the start of the experiment, which were dried in a vacuum freezer at $-60^{\circ} \mathrm{C}$

room and the microcosms within blocks using random number tables.

Litter mass loss, $\mathrm{CO}_{2}$ production, and litter fragmentation

The experiment lasted for 9 weeks. Litter fragmentation, $\mathrm{CO}_{2}$ production, and litter mass loss were determined as measures of decomposition. The first $\mathrm{CO}_{2}$ respiration measurements were made at 7 days after the start of the incubation period, and measurements were performed at 6- to 10-day intervals (median 7 days) thereafter, up to day $55,59,56,57$ and 57 for Blocks 1-5, respectively. For $\mathrm{CO}_{2}$ measurements, the bottom and top of the microcosms were closed with air-tight lids, and a 5-ml gas sample was taken with an injection needle, after which the $\mathrm{CO}_{2}$ concentration was measured on an EGM-4 infrared gas analyzer (PP Systems, Hertfordshire, UK). In order to maintain a stable air pressure in the microcosms, $5 \mathrm{ml} \mathrm{N} \mathrm{N}_{2}$ was added in return. After $1 \mathrm{~h}$, a second 5-ml gas sample was taken and analyzed. $\mathrm{CO}_{2}$ measurements were corrected for average soil respiration that was measured in the control microcosms without litter.

We calculated $\mathrm{CO}_{2}$ production $\left(C_{\text {prod }}\right.$, in $\left.\mathrm{mg} \mathrm{CO}_{2} \mathrm{~h}^{-1}\right)$ as follows:

$$
\begin{aligned}
C_{\text {prod }}= & \left(\left(C_{t=1}+C_{\text {sample }}\right) \times\left(\frac{44.01 \times 1000}{23.398 \times 10^{9}}\right) \times V\right) \\
& -\left(C_{t=0} \times\left(\frac{44.01 \times 1000}{23.398 \times 10^{9}}\right) \times V\right),
\end{aligned}
$$

where $C_{t=0}$ is the initial $\mathrm{CO}_{2}$ concentration (in ppm); $C_{t=1}$ is the $\mathrm{CO}_{2}$ concentration $1 \mathrm{~h}$ after closure; 44.01 is the molar mass $\left(\mathrm{g} \mathrm{mol}^{-1}\right.$ ) of $\mathrm{CO}_{2}$ (multiplied by 1,000 to convert from $\mathrm{g}$ to $\mathrm{mg}$ ); 23.398 is the molar volume at $12^{\circ} \mathrm{C}$ (in
$1 \mathrm{~mol}^{-1}$; after linear interpolation between molar volume at 0 and $25^{\circ} \mathrm{C}$ ) (multiplied by $10^{9}$ to convert $\mu 11^{-1}$ to $\mathrm{ml}^{-1}$ ); $V$ is the microcosm volume (in $\mathrm{ml}$ ), which was measured by filling one microcosm (filled with either rewetted $A$. incana or B. pubescens leaves) with water on a scale, where a $1 \mathrm{~g}$ increase in weight equals $1 \mathrm{ml}$ of volume. Microcosm volumes were corrected for the volume of the layer of river sand, which was determined visually in a measuring cylinder, and thereafter corrected for the air fraction between the sand particles by measuring how much water was needed to saturate a known volume of sand. $C_{\text {sample }}$ is to correct for the decrease in $\mathrm{CO}_{2}$ concentration in the microcosms after the first 5-ml gas sample was taken to measure $C_{t=0}$ and $5 \mathrm{ml}$ of $\mathrm{N}_{2}$ had been added in return, and was calculated as follows:

$C_{\text {sample }}=C_{t=0} \times \frac{V}{V-5}-C_{t=0}$.

At the end of the experiment, the dry weight of the macro-detritivores after depuration was recorded after drying for 5 days in a vacuum freeze-drier at $-60^{\circ} \mathrm{C}$ (EF4 Modulyo; Edwards High Vacuum, Crawley, UK). All animals found dead in the microcosm were recorded, but overall mortality was very low (L. rubellus $3.9 \%$, O. asellus $0 \%$, J. scandinavius $1.3 \%$ ). All animals that could not be found, alive nor dead, were considered to have escaped. Millipede escapes were highest-in total $25.3 \%$ whereas only two $O$. asellus and one L. rubellus escaped. Escapes were equally distributed over the different treatments. We assumed that dead animals died in the first week of the experiment, and given that animals could only have escaped during the first week of the experiment, we assumed that the influence of missing animals on decomposition was negligible. We therefore excluded them 
from macro-detritivore biomass measurements and further analyses. Litter from the microcosms was dried to constant weight at $70^{\circ} \mathrm{C}$.

For litter fragmentation measurements, dry litter was sieved through 16-, 8-, 4-, 2-, and 1-mm sieves to obtain six size classes (Heemsbergen et al. 2004). Differences in litter size classes before and after the experiment were quantified using a Bray-Curtis measure for dissimilarity $(B)$, which ranges between 0 (similar) and 1 (dissimilar) (Krebs 1999):

$B=\frac{\sum_{i=5}^{n}\left(X_{i j}-X_{i k}\right)}{\sum_{i=5}^{n} X_{i j}+X_{i k}}$,

in which $X_{i j}$ and $X_{i k}$ are the amounts of litter $(\mathrm{g})$ in the different size classes $I$ before and after the experiment, respectively. The smallest size class $(<1 \mathrm{~mm})$ was excluded from calculations because it only contained sand.

Litter dry weight of the five litter size classes was summed to obtain total litter dry weight after decomposition [corrected for sand contamination by determining the loss on ignition (LOI) at $500^{\circ} \mathrm{C}$ ], based on which we calculated percentage (\%) litter mass loss. We assumed that the sand fraction was equal in all litter size classes and subsequently corrected fragmentation calculations for sand contamination.

The litter mass loss, $\mathrm{CO}_{2}$ production, and fragmentation that were measured in the control treatments were used as corrections for the treatment measurements to single out the macro-detritivore-induced decomposition. The three decomposition parameters were also corrected for the added macro-detritivore biomass.

\section{Statistical analyses}

Statistical analyses were performed in SPSS ver. 15.0 for Windows. Litter fragmentation data (Bray-Curtis measures of dissimilarity, uncorrected for the added macro-detritivore biomass) was $\log _{10}$-transformed prior to analyses in order to meet assumptions of normality (KolmogorovSmirnov test) and homogeneity of variances (Levene's test).

We tested whether the macro-detritivore effects on litter mass loss (both $\%$ and $\% \mathrm{~g}^{-1} \mathrm{DW}$ macro-detritivore) were significantly different from zero (hypothesis 1) using onesample $t$ tests. Differences between macro-detritivore treatments on litter decomposition processes (hypothesis 2) were first tested using two-way analyses of variance (ANOVAs) with macro-detritivore treatment, litter type, and litter $\times$ macro-detritivore treatment as factors and litter mass loss, litter respiration, and fragmentation as dependent variables. Blocks were randomly rotated within the climate room and therefore not used as a factor in the ANOVAs. In the case of a significant litter $\times$ macro- detritivore treatment interaction, we distinguished between the two litter types and tested the effects of macro-detritivores on $A$. incana and $B$. pubescens mass loss using separate one-way ANOVAs for both litter types, with macro-detritivore treatment as a factor. Tukey's HSD post hoc tests were used when ANOVA results were significant.

We used one-sample $t$ tests to determine whether macrodetritivore combinations lead to net diversity effects on decomposition (hypothesis 3). To this end, we calculated net diversity effects (Loreau and Hector 2001; Heemsbergen et al. 2004) by first calculating the expected litter mass loss $(\%)$ of the combined macro-detritivore treatments as the weighed mean mass loss of the single macro-detritivore treatments. The difference between observed and expected mass loss was subsequently calculated, after which we tested whether this difference significantly differed from zero. The same was done for cumulative $\mathrm{CO}_{2}$ production (mg), litter fragmentation (B-C dissimilarity), and macrodetritivore biomass-corrected decomposition parameters.

\section{Results}

Macro-detritivore effects on subarctic litter decomposition

The three macro-detritivores in monoculture significantly increased \% litter mass loss of $A$. incana, but not of B. pubescens litter, whereas combinations of macro-detritivores increased \% litter mass loss in both litter types, except for the $\mathrm{M}+\mathrm{I}$ treatment of B. pubescens (Table 2). When expressed as per gram added macro-detritivore, all macro-detritivore treatments (monocultures and combinations) significantly increased litter mass loss, except for the $\mathrm{M}$ and $\mathrm{M}+\mathrm{I}$ treatment of B. pubescens litter (Table 2).

There were significant differences in $\%$ mass loss between macro-detritivore treatments and litter types, as well as a significant litter $\times$ macro-detritivore treatment interaction in \% litter mass loss (Table 3). Averaged over all treatments (including control treatments), litter mass loss was twice as high in $A$. incana litter than in $B$. pubescens litter $[26 \pm 10 \%$ (SD) vs. $13 \pm 7 \%$, respectively; Student's $t$ test $t=7.004, d f=78, P<0.001]$. For both litter types, the highest mass loss occurred in the treatments where earthworms were added (Fig. 1a). However, when mass loss was expressed per gram added macro-detritivore biomass, there were no significant differences between macro-detritivore treatments or litter types (Table 3, Fig. 1d).

Cumulative $\mathrm{CO}_{2}$ production differed significantly between litter types $(1113 \pm 17 \mathrm{mg}$ in A. incana vs. $1177 \pm 161 \mathrm{mg}$ in B. pubescens litter) and treatments 
Table 2 Results of one-sample $t$ tests for testing whether the net effects of macro-detritivores on mass loss (both $\%$ and $\% / g$ DW macrodetritivores) was significantly different from zero after correction for mass loss in the control treatments

\begin{tabular}{|c|c|c|c|c|c|}
\hline \multirow[t]{2}{*}{ Dependent variable } & \multirow[t]{2}{*}{ Litter } & \multirow[t]{2}{*}{ Treatment $^{\mathrm{a}}$} & \multicolumn{3}{|c|}{$t$ test results } \\
\hline & & & Mean & $t$ & $P$ \\
\hline \multirow[t]{14}{*}{ Mass loss (\%) } & \multirow[t]{7}{*}{ A. incana } & $\mathrm{E}$ & 22.5 & 5.738 & 0.005 \\
\hline & & M & 6.3 & 3.421 & 0.027 \\
\hline & & I & 9.4 & 2.960 & 0.042 \\
\hline & & $E+M$ & 17.2 & 4.679 & 0.009 \\
\hline & & $\mathrm{E}+\mathrm{I}$ & 17.0 & 8.111 & 0.001 \\
\hline & & $M+I$ & 9.1 & 3.287 & 0.030 \\
\hline & & $\mathrm{E}+\mathrm{M}+\mathrm{I}$ & 27.1 & 16.927 & $<0.001$ \\
\hline & \multirow[t]{7}{*}{ B. pubescens } & $\mathrm{E}$ & 7.6 & 2.407 & 0.074 \\
\hline & & M & 2.5 & 1.123 & 0.324 \\
\hline & & I & 4.1 & 2.259 & 0.087 \\
\hline & & $E+M$ & 13.8 & 5.816 & 0.004 \\
\hline & & $\mathrm{E}+\mathrm{I}$ & 15.4 & 8.450 & 0.001 \\
\hline & & $M+I$ & 5.0 & 1.408 & 0.232 \\
\hline & & $\mathrm{E}+\mathrm{M}+\mathrm{I}$ & 9.0 & 8.286 & 0.001 \\
\hline \multirow[t]{14}{*}{ Mass loss ( $\% \mathrm{~g}^{-1} \mathrm{DW}$ macro-detritivore $)$} & \multirow[t]{7}{*}{ A. incana } & $\mathrm{E}$ & 62.5 & 4.564 & 0.010 \\
\hline & & M & 66.4 & 4.294 & 0.013 \\
\hline & & I & 55.7 & 6.718 & 0.003 \\
\hline & & $\mathrm{E}+\mathrm{M}$ & 66.3 & 7.667 & 0.002 \\
\hline & & $\mathrm{E}+\mathrm{I}$ & 42.1 & 5.611 & 0.005 \\
\hline & & $M+I$ & 75.8 & 2.905 & 0.044 \\
\hline & & $\mathrm{E}+\mathrm{M}+\mathrm{I}$ & 54.5 & 10.113 & 0.001 \\
\hline & \multirow[t]{7}{*}{ B. pubescens } & $\mathrm{E}$ & 49.3 & 4.753 & 0.009 \\
\hline & & M & 33.6 & 2.090 & 0.105 \\
\hline & & I & 29.3 & 4.867 & 0.008 \\
\hline & & $\mathrm{E}+\mathrm{M}$ & 40.4 & 7.709 & 0.002 \\
\hline & & $\mathrm{E}+\mathrm{I}$ & 46.5 & 7.886 & 0.001 \\
\hline & & $M+I$ & 43.2 & 2.509 & 0.066 \\
\hline & & $\mathrm{E}+\mathrm{M}+\mathrm{I}$ & 33.3 & 8.640 & 0.001 \\
\hline
\end{tabular}

$d f=4$ in all cases

${ }^{\text {a }}$ Addition of earthworm (E), millipede (M), and/or isopod (I) to microcosm with liter

(Table 3, Fig. 1b), and there was no significant interaction between litter type and macro-detritivore treatment (as was also the case for the other parameters; Table 3). Therefore, the responses of both litter types are combined in Fig. 1. The three macro-detritivores did not differ in their stimulatory effect on $\mathrm{CO}_{2}$ production, but there were differences between the macro-detritivore mixtures. As was the case for $\%$ mass loss, the overall highest $\mathrm{CO}_{2}$ production occurred in the treatments where earthworms were present (Fig. 1b). When cumulative $\mathrm{CO}_{2}$ production is expressed per gram added macro-detritivore, there were no significant differences between the treatments (Table 3; Fig. 1e). There was a significant but low correlation between mass loss (\%) and cumulative $\mathrm{CO}_{2}$ production (Pearson's $r=0.349$, $P=0.001)$. However, this correlation disappeared when mass loss was expressed per gram added macro-detritivore biomass (Pearson's $r=-0.100, P=0.409$ ).

Litter fragmentation also differed between litter types and macro-detritivore treatments (Table 3, Fig. 1c). On average, litter fragmentation (Bray-Curtis measure for dissimilarity in litter fragment size classes) was higher (larger increase in small litter fragments) in A. incana than in $B$. pubescens litter $(0.3 \pm 0.06$ and $0.2 \pm 0.03$, respectively; Student's $t$-test $t=0.534, d f=78, P<0.001)$. Surprisingly, earthworms were the strongest fragmenting species, and litter was significantly more fragmented in all 
Table 3 Results of two-way analyses of variance for decomposition measures according to dependency on litter type and macro-detritivore treatment

\begin{tabular}{|c|c|c|c|c|}
\hline Decomposition measure/treatment & SS & $d f$ & $F$ & $P$ \\
\hline \multicolumn{5}{|l|}{ Mass loss $(\%)$} \\
\hline Litter type & 933.378 & 1 & 26.767 & $<0.001$ \\
\hline Macro-detritivore treatment & 1853.722 & 6 & 8.860 & $<0.001$ \\
\hline Litter type $\times$ macro-detritivore treatment & 621.633 & 6 & 2.971 & 0.014 \\
\hline \multicolumn{5}{|l|}{$\mathrm{CO}_{2}$ production $(\mathrm{mg})$} \\
\hline Litter type & 54475.309 & 1 & 1.718 & 0.195 \\
\hline Macro-detritivore treatment & 620094.731 & 6 & 3.259 & 0.008 \\
\hline Litter type $\times$ macro-detritivore treatment & 95317.786 & 6 & 0.501 & 0.805 \\
\hline \multicolumn{5}{|l|}{ Fragmentation (Bray-Curtis dissimilarity) } \\
\hline Litter type & 0.710 & 1 & 12.833 & 0.001 \\
\hline Macro-detritivore treatment & 4.532 & 6 & 13.651 & $<0.001$ \\
\hline Litter type $\times$ macro-detritivore treatment & 0.352 & 6 & 1.059 & 0.399 \\
\hline \multicolumn{5}{|l|}{ Mass loss ( $\% \mathrm{~g}^{-1} \mathrm{DW}$ macro-detritivore $)$} \\
\hline Litter type & 2540.682 & 1 & 4.941 & 0.030 \\
\hline Macro-detritivore treatment & 3615.873 & 6 & 1.172 & 0.334 \\
\hline Litter type $\times$ macro-detritivore treatment & 1107.081 & 6 & 0.359 & 0.902 \\
\hline \multicolumn{5}{|l|}{$\mathrm{CO}_{2}$ production ( $\mathrm{mg} \mathrm{g}^{-1} \mathrm{DW}$ macro-detritivore) } \\
\hline Litter type & 914813.791 & 1 & 2.587 & 0.113 \\
\hline Macro-detritivore treatment & 2434135.047 & 6 & 1.147 & 0.348 \\
\hline Litter type $\times$ macro-detritivore treatment & 666338.796 & 6 & 0.314 & 0.927 \\
\hline \multicolumn{5}{|c|}{ Fragmentation (Bray-Curtis dissimilarity $\mathrm{g}^{-1} \mathrm{DW}$ macro-detritivore) } \\
\hline Litter type & 0.011 & 1 & 2.097 & 0.153 \\
\hline Macro-detritivore treatment & 0.288 & 6 & 6.720 & $<0.001$ \\
\hline Litter type $\times$ macro-detritivore treatment & 0.025 & 6 & 0.810 & 0.567 \\
\hline
\end{tabular}

The $F$ values for the main effects and their interactions are presented, together with their level of significance

macro-detritivore treatments which included earthworms as compared to treatments without earthworms (Fig. 1c). When litter fragmentation was expressed per gram added macro-detritivore biomass, there were still differences between macro-detritivores in their fragmenting abilities, with the highest litter fragmentation found in the $\mathrm{E}$ and $\mathrm{E}+\mathrm{M}+\mathrm{I}$ treatments (Fig. 1f). $\log _{10}$-transformed litter fragmentation data correlated very well with percentage mass loss (Pearson's $r=0.888, P<0.001$ ), whereas the correlation between $\log _{10}$-transformed litter fragmentation and cumulative $\mathrm{CO}_{2}$ production was not significant (Pearson's $r=0.201, P=0.074$ ).

\section{NDEs of macro-detritivores}

The NDEs for $\%$ litter mass loss were positive (i.e., the observed mass loss was larger than the expected mass loss based on the average of the single macro-detritivore treatments) in the $\mathrm{E}+\mathrm{M}+\mathrm{I}$ treatment with $A$. incana litter $(P=0.005)$ and in the $\mathrm{E}+\mathrm{M}$ treatment with $B$. pubescens litter $\left(P=0.043\right.$; Fig. 2a). For cumulative $\mathrm{CO}_{2}$ production, we found significant positive NDE again in the A. incana $\mathrm{E}+\mathrm{M}+\mathrm{I} \quad(P=0.023)$ and $B$. pubescens $\mathrm{E}+\mathrm{M}$ $(P=0.035$; Fig. $2 b)$ treatments. Also for litter fragmentation, positive NDE occurred in the same treatments ( $P=0.009$ for both treatments) and, in addition, also in the B. pubescens $\mathrm{E}+\mathrm{M}+\mathrm{I}$ treatment $(P=0.041$; Fig. $2 \mathrm{c})$. Inhibitory effects $(\mathrm{NDE}<0)$ were not observed. However, when decomposition parameters were expressed per gram added macro-detritivore biomass, we observed no NDEs in any of the decomposition parameters (Fig. 3).

We also tested the effect of macro-detritivore species number on decomposition parameters [Electronic Supplementary Material (ESM) 1] and found that species number had a positive effect on mass loss (A. incana: $R^{2}=0.20$, $P=0.007 ;$ B. pubescens: $\left.R^{2}=0.12, P=0.044\right)$ and litter fragmentation (A. incana: $R^{2}=0.22, P=0.005 ; B . p u$ bescens: $\left.R^{2}=0.19, \quad P=0.005\right)$ when decomposition parameters were not corrected for macro-detritivore biomass. However, this relationship is driven by biomass 
Fig. 1 Effects of different macro-detritivore treatments on: a mass loss (\%), b cumulative $\mathrm{CO}_{2}$ production (mg), $\mathbf{c}$ litter fragmentation (Bray-Curtis $(B-C)$ dissimilarity), d mass loss $\left[\% \mathrm{~g}^{-1}\right.$ dry weight $(D W)$ macro-detritivore $(M D)]$, e cumulative $\mathrm{CO}_{2}$ production ( $\mathrm{mg} \mathrm{g}^{-1}$ DW MD), f litter fragmentation $(\mathrm{B}-\mathrm{C}$ dissimilarity, $\mathrm{g}^{-1}$ DW MD). $x$-Axis: $E$ earthworm addition, $M$ millipede addition, $I$ isopod addition. White bars Alnus incana, gray bars Betula pubescens. Error bars: 1 standard error of the mean (SEM; $n=5$ ). Different letters above bars indicate significant differences $(P<0.05)$ among treatments
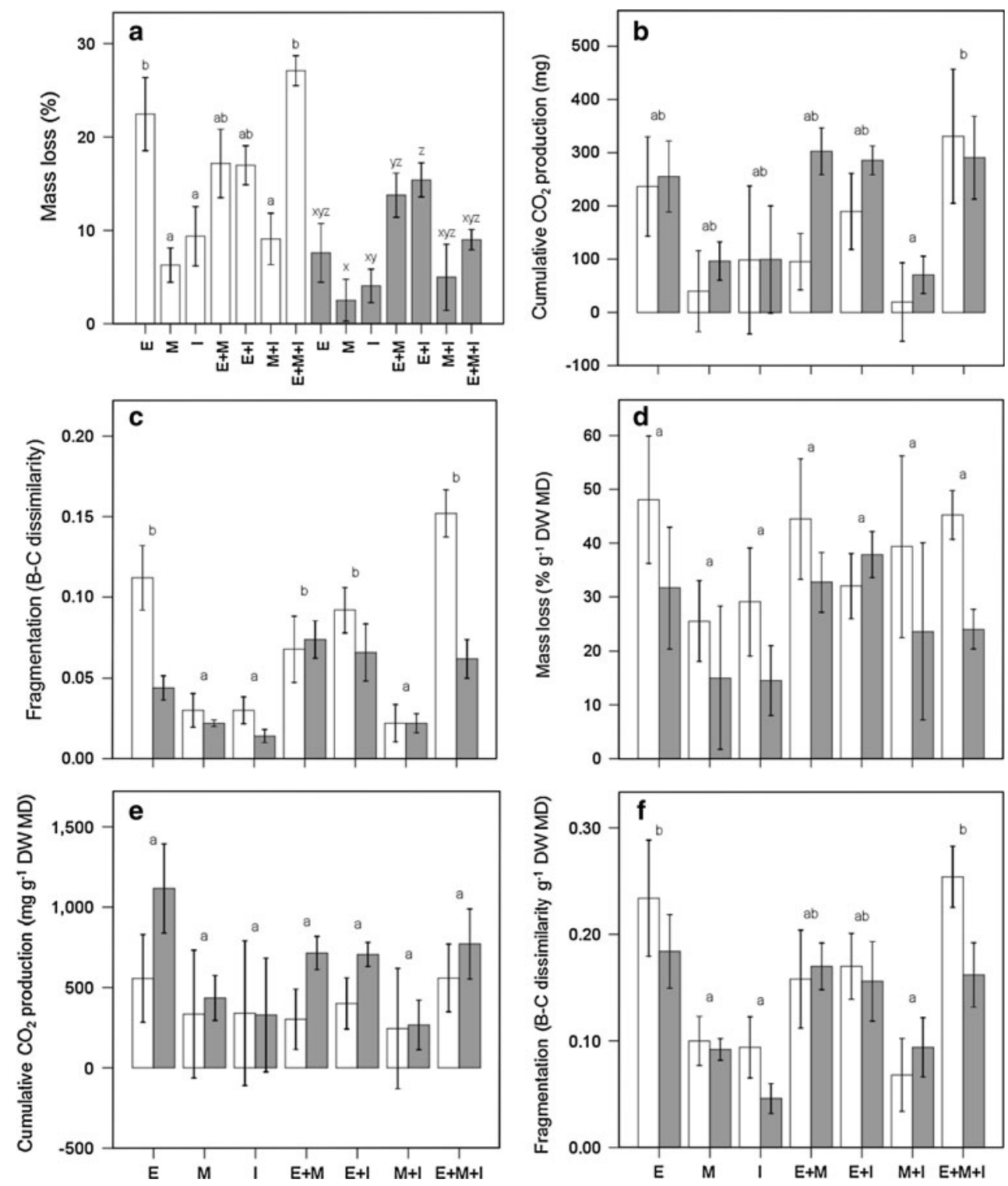

because after correction for macro-detritivore biomass there were no positive relationships between species number and decomposition parameters.

\section{Discussion}

Macro-detritivore effect on litter decomposition in the subarctic

To the best of our knowledge, this is the first study in which the potential effect of expected macro-detritivore northward range expansions on subarctic litter decomposition rates is tested. Our finding that macro-detritivores stimulate litter mass loss, thereby supporting our first hypothesis, is of particular importance because potential climate change-driven northern range expansions might thus provide a positive feedback mechanism to climate warming (Aerts 2006; Dorrepaal et al. 2009). The occurrence of macro-detritivore effects on litter decomposition rates is broadly accepted (Scheu and Parkinson 1994; Seatre 1998; Cárcamo et al. 2000; Hättenschwiler and Bretscher 2001; Heemsbergen et al. 2004; Vos et al. 2011). Indeed, the presence of a macro-detritivore has been shown to have a stronger positive effect on decomposition rates than a $3^{\circ} \mathrm{C}$ temperature increase in a Swiss forest (Rouifed et al. 2010). However, the macrodetritivore effect on litter decomposition has never before been demonstrated on subarctic leaf litter, despite the fact that macro-detritivores are likely to invade the subarctic 


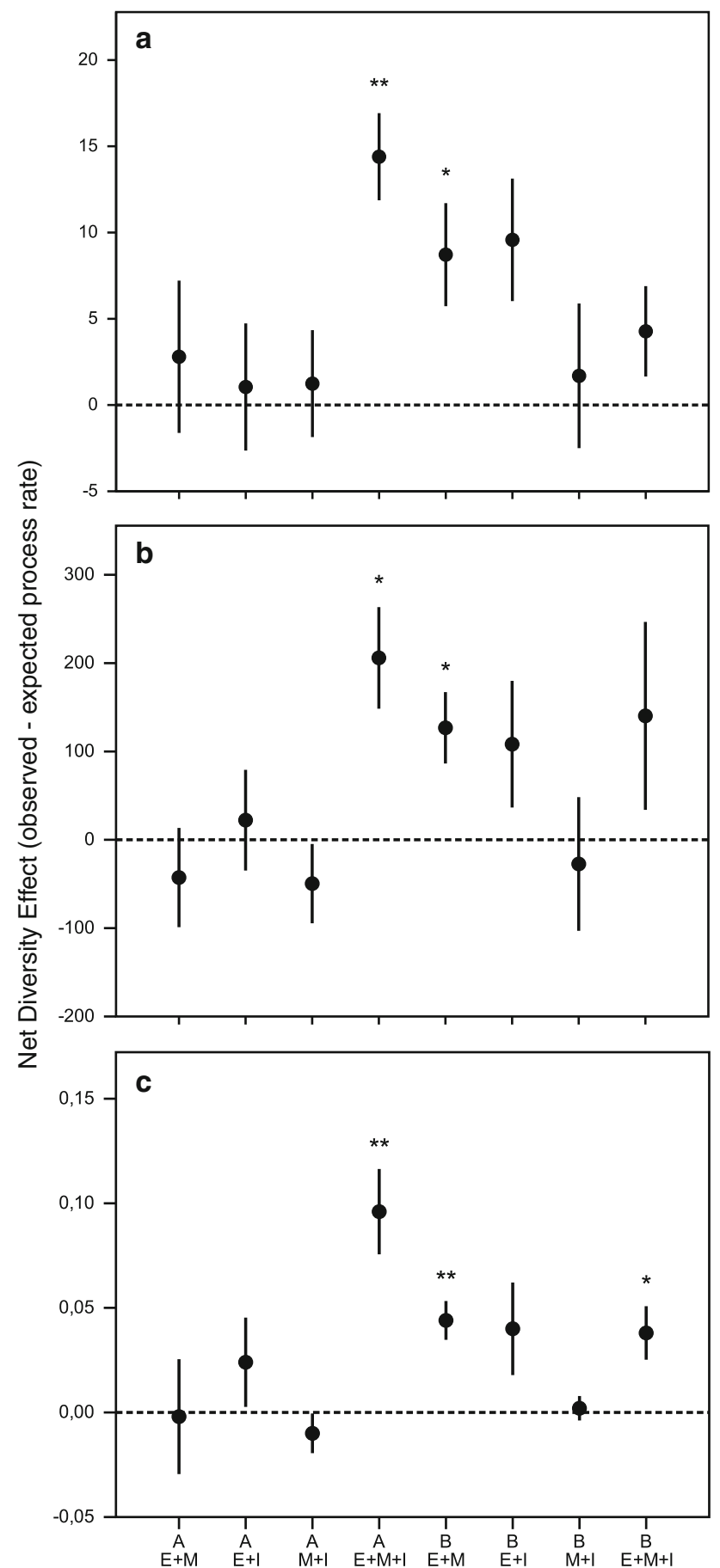

Fig. 2 Net diversity effects (NDE) of the various combinations of macro-detritivores. Dots represent the mean difference between observed and expected \% mass loss (a), cumulative $\mathrm{CO}_{2}$ production $(\mathrm{mg} ; \mathbf{b})$, and litter fragmentation (B-C dissimilarity; c). Error bars: 1 SEM $(n=5)$. NDE $=0$, no diversity effect; NDE $>0$, facilitative effect; NDE $<0$, inhibitory effect. $x$-Axis: A A. incana litter, $B$ B. pubescens litter. $* * P<0.01, * P<0.05$

under future climate regimes. The consequence of the potential macro-detritivore range expansions into subarctic regions, therefore, could be an increased carbon

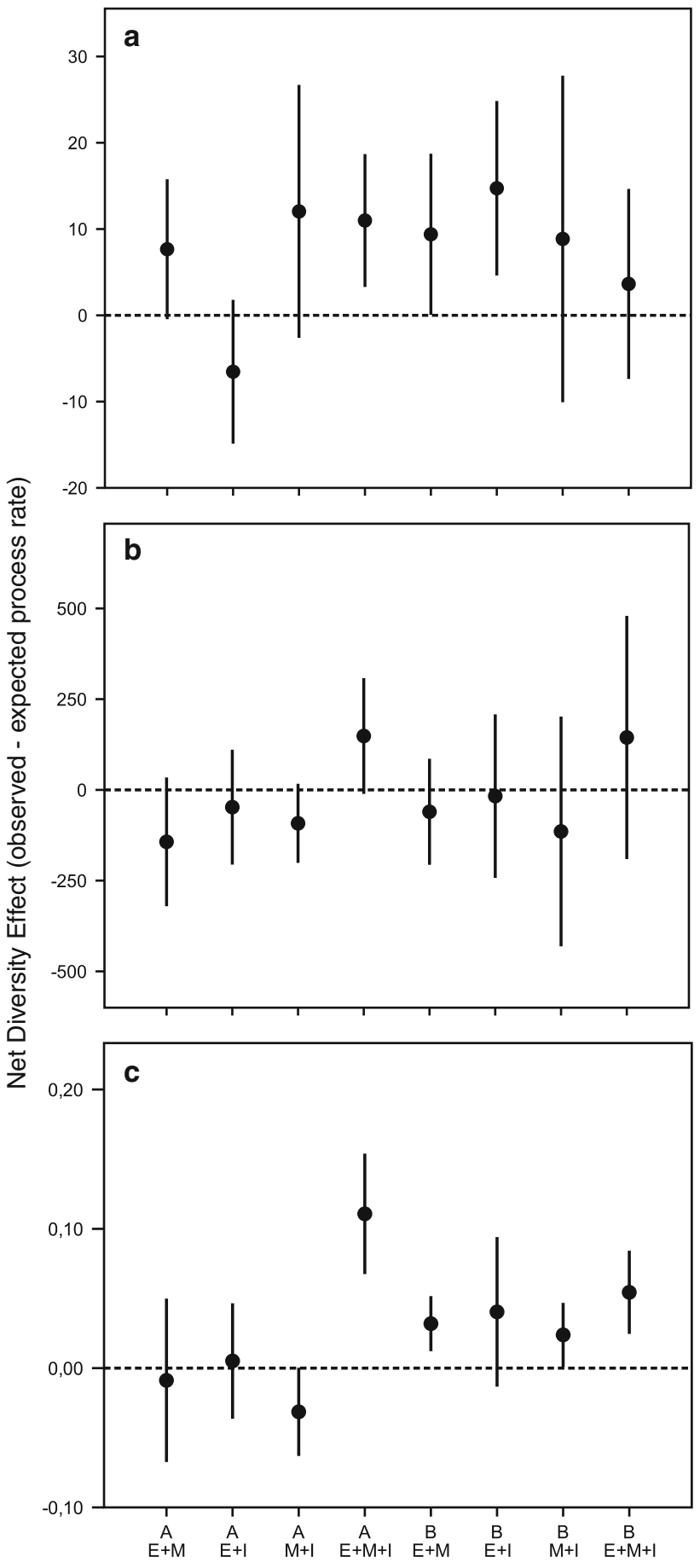

Fig. 3 NDE of various combinations of macro-detritivores after correction for the added macro-detritivore biomass. Dots represent the mean difference between observed and expected mass loss (\% $\mathrm{g}^{-1} \mathrm{DW}$ macro-detritivore; a), cumulative $\mathrm{CO}_{2}$ production $\left(\mathrm{mg} \mathrm{g}^{-1}\right.$ DW macro-detritivore; b), and litter fragmentation (B-C dissimilarity, $\mathrm{g}^{-1}$ DW macro-detritivore; c). Error bars: 1 SEM $(n=5)$

flux to the atmosphere, adding further complexity to the problem of predicting whether cold biomes will be net sources or sinks of atmospheric carbon under future 
climate change scenarios (Cornelissen et al. 2007; Wookey et al. 2009).

The macro-detritivore effect on litter decomposition does, however, depend on litter quality. Macro-detritivores have been shown to be selective feeders, preferring organic matter with high nitrogen contents and low amounts of structural compounds, such as lignin and secondary metabolites (Hendriksen 1990; Hättenschwiler and Bretscher 2001). However, the macro-detritivore effect on decomposition has also been shown to be more pronounced in poor quality litter than in high-quality litter (Tian et al. 1995; Cárcamo et al. 2000). This more pronounced effect in poor quality litter has been ascribed to (1) the relatively easy decomposition of high-quality litter, which is not further facilitated by macro-detritivore interruption (Tian et al. 1995) and (2) 'compensatory feeding' in low-quality litter, i.e., animals increase their consumption on litter of poor quality to meet their nutrient (especially $\mathrm{N}$ ) requirements (Coûteaux et al. 1991; Hättenschwiler et al. 1999). In our study, high-quality $A$. incana litter decomposed significantly faster than lower quality B. pubescens litter when all treatments were pooled. Moreover, all macrodetritivore treatments had a significant effect on A. incana mass loss, whereas this was not the case in several macrodetritivore treatments with B. pubescens litter (Table 2). Hence, in contrast to our expectation, the macro-detritivore effect was most pronounced in the high-quality A. incana litter. Although this contrasts the compensatory feeding hypothesis and the suggestion that high-quality litter mass loss is not greatly facilitated by macro-detritivore consumption, it is in line with results from a previous study that did not show these effects of litter quality on macrodetritivore consumption either (David et al. 2001). A possible explanation may lay in the overall lower quality of subarctic litter types compared to the litters of other biomes.

Our results only partly support our second hypothesis that macro-detritivore identity determines the effects on decomposition, because earthworms caused the greatest increases in litter mass loss of A. incana, but their stimulatory effect was not higher than those of millipedes and isopods on B. pubescens litter (Fig. 1a). Earthworms also had the strongest stimulatory effect on litter fragmentation (Fig. 1c). However, when litter decomposition parameters were corrected for macro-detritivore biomass, differences between macro-detritivore species disappeared, except for litter fragmentation (Fig. 1d-f), indicating that per gram biomass the net effect of all macro-detritivores is similar and that the 'identity effect' of the earthworms is largely caused by their higher biomass and not by a specific functional trait.
NDEs of macro-detritivores

Despite the fact that biodiversity effects on ecosystem processes constitute a central issue in ecology (Loreau and Hector 2001; Gessner et al. 2010), relatively few studies have considered the importance of macro-detritivore diversity effects on ecosystem processes to date (Gessner et al. 2010; Vos et al. 2011). The few studies that are currently available indicate that NDEs of macro-detritivore combinations can occur and dominate over species richness effects (Chong et al. 2000; Heemsbergen et al. 2004; Zimmer et al. 2005; De Oliveira et al. 2010; Hedde et al. 2010). Therefore, facilitative or inhibitory interactions among macro-detritivores can be crucial for predicting potential macro-detritivore effects on future subarctic decomposition rates. Indeed, we showed that NDEs in macro-detritivore mixtures also occur under subarctic conditions (Fig. 2). For example, significant positive NDEs were observed in the $\mathrm{E}+\mathrm{M}+\mathrm{I}$ treatment with $A$. incana litter and the $\mathrm{E}+\mathrm{M}$ and $\mathrm{E}+\mathrm{I}$ treatment with $B$. pubescens litter (Fig. 2a). However, when corrected for macrodetritivore biomass, we observed no significant NDEs in any of the decomposition parameters (Fig. 3). Nevertheless, when mass loss was corrected for macro-detritivore biomass, more treatments had a positive NDE close to (or beyond) $+10 \%$ mass loss (Fig. 3a) than without correction for macro-detritivore biomass (Fig. 2a). The absence of significant NDEs after correction for biomass is probably due to the large variances accompanying the biomasscorrected NDEs, thereby greatly reducing the power of the statistical analyses. This increased variance probable results from large intra-specific variation in water contents of the macro-detritivores. Therefore, we cannot draw any hard conclusions as yet on the occurrence of NDEs in macro-detritivore mixtures feeding on subarctic leaf litter.

NDEs in plant studies can conveniently be statistically partitioned into complementarity effects (positive species interactions or resource partitioning) and selection effects (one species has a large influence on a certain process, both in monoculture and in mixtures) (Loreau and Hector 2001). In contrast, partitioning the two possible mechanisms is problematic in studies on NDEs using animals, since the individual contribution of the different species in a mixture cannot be measured directly. As such, our study design did not allow for partitioning NDEs into complementarity effects or selection effects. Nevertheless, previous studies on macro-detritivore diversity effects on ecosystem processes did show that NDEs resulted from facilitation by functionally dissimilar species (Heemsbergen et al. 2004; De Oliveira et al. 2010). However, NDEs were not related to functional dissimilarity of macro-detritivores in our study (ESM 2). 
Hence, macro-detritivore body mass seems to be an important determinant of the increase in decomposition rates when macro-detritivores expand their ranges into subarctic regions. After all, interspecific differences in decomposition stimulating effects of macro-detritivores are driven by a consistent variation in biomass. Our results indicate that NDEs can also be driven by variation in body mass but that a large variance in biomass-corrected NDEs on litter mass loss interferes with a generally positive NDE in different macro-detritivore combinations (Fig. 3a). The general increase in litter mass loss and fragmentation with macro-detritivore species number was not observed when data was corrected for the added macro-detritivore biomass (ESM 1), indicating that macro-detritivore biomass is the driving force behind species number effects on decomposition, whereas species number per se has no direct effect, as was also found by Heemsbergen et al. (2004). Consequently, the ecosystem consequences of macro-detritivore range expansions are therefore likely to depend mainly on the body mass of the macro-detritivore species, rather than on species number or functional identity, although positive species interactions might increase litter mass loss rates.

Up-scaling from microcosms to the real world

We have determined, as a proof of principle, the potential effects of the range expansion of macro-detritivores on the litter decomposition of subarctic plant species in microcosms under subarctic summer conditions. As such, this is a strong simplification of the 'real world'. We realize that these conditions are not representative of less favorable conditions in other subarctic seasons since macro-detritivore activity is strongly related to temperature, photoperiod, and moisture (Hopkin and Read 1992; Warburg 1993; Edwards and Bohlen 1996).

Many macro-detritivores are rather limited in their active dispersal abilities. Nevertheless, there is evidence for substantial macro-detritivore range expansions in response to a warming climate in the UK (Hickling et al. 2006). In addition, if environmental conditions are suitable, human-aided passive dispersal could mediate the introduction of macro-detritivores in the subarctic. The relative importance of active versus passive dispersal in macrodetritivores has not yet been quantified, although there are indications that long-distance macro-detritivore dispersal is facilitated or even fully mediated by anthropogenic transport (Bohlen et al. 2004; Tiunov et al. 2006). Obtaining more detailed estimates for the velocity of both passive and active range expansions, from observational and modeling studies, could improve our insights in macro-detritivore range expansions.
In our study design, biotic interactions with native subarctic flora and fauna are ignored, despite the great importance of both these factors on potential invasions, as they may influence species distribution (Berggren et al. 2009) and thus future community composition (Berg et al. 2010), as well as species effects on ecosystems. For example, the net effects of macro-detritivores on decomposition may also depend on interactions with the microbial community (Brown 1995). It has been shown that macro-detritivores influence microbial biomass and increase the bacterial:fungal ratios (Scheu and Parkinson 1994), which might have profound consequences on decomposition rates (Bailey et al. 2002). Although we did inoculate the litters with subarctic bacterial and fungal inoculum, the growth conditions for these microorganisms were of course highly artificial. These considerations emphasize the need for field studies with controlled macro-detritivore introductions, in which biotic interactions can be taken into account.

\section{Conclusions}

Potential macro-detritivore range expansions into subarctic regions will result in accelerated decomposition and an accompanying increased carbon flux into the atmosphere, providing a potential, as yet unstudied, positive ecosystem feedback mechanism to climate change. Macro-detritivore species number and functional identity seem to be unimportant for the potential macro-detritivore effects on subarctic decomposition, while species-specific differences in body mass represent the driving force behind the macrodetritivore stimulation of subarctic decomposition. Hence, a higher macro-detritivore biomass in the subarctic, irrespective of macro-detritivore species number or functional identity, will result in faster decomposition process rates. The next steps to be taken are detailed monitoring studies and the generation of accurate predictions of macro-detritivore range expansions into subarctic regions; controlled introduction experiments under field conditions also need to be performed.

Acknowledgments We are grateful to Jurgen van Hal, Richard van Logtestijn, and Rudo Verweij for practical assistance, and to Janneke Ravenek and the other students on the Kronåsvägen in Uppsala for their hospitality. Thanks are due to Hans Cornelissen, Jeroen Cornelissen, and Cassandra van Altena for their help with litter collection. This study was supported by grant 851.30 .023 of the Research Council for Earth and Life Sciences (ALW) with financial aid from the Netherlands Organization for Scientific Research (NWO) to RA.

Open Access This article is distributed under the terms of the Creative Commons Attribution Noncommercial License which permits any noncommercial use, distribution, and reproduction in any medium, provided the original author(s) and source are credited. 


\section{References}

Aerts R (2006) The Freezer defrosting: global warming and litter decomposition rates in cold biomes. J Ecol 94:713-724. doi: $10.1111 /$ j.1365-2745.2006.01142.x

Bailey VL, Smith JL, Bolton H Jr (2002) Fungal-to-bacterial ratios in soils investigated for enhanced $\mathrm{C}$ sequestration. Soil Biol Biochem 34:997-1007. doi:10.1016/S0038-0717(02)00033-0

Berg MP, Kiers TE, Driessen G, Van der Heijden M, Kooi BW, Kuenen F, Liefting M, Verhoef HA, Ellers J (2010) Adapt or disperse: understanding species persistence in a changing world. Glob Change Biol 16:587-598. doi:10.1111/j.1365-2486.2009. 02014.x

Berggren A, Björkman C, Bylund H, Ayres MP (2009) The distribution and abundance of animal populations in a climate of uncertainty. Oikos 118:1121-1126. doi:10.1111/j.1600-0706. 2009.17558.x

Bohlen PJ, Scheu S, Hale CM, McLean MA, Migge S, Groffman PM, Parkinson D (2004) Non-native invasive earthworms as agents of change in northern temperate forests. Front Ecol Environ 2:427-435. doi:10.1890/1540-9295(2004)002

Briones MJ, Ineson P, Heinemeyer A (2007) Predicting potential impacts of climate change on the geographical distribution of enchytraeids: a meta-analysis approach. Glob Change Biol 13:2252-2269. doi:10.1111/j.1365-2486.2007.01434.x

Brown GG (1995) How do earthworms affect microfloral and faunal community diversity? Plant Soil 170:209-231. doi:10.1007/ BF02183068

Cárcamo HA, Abe TA, Prescott CE, Holl FB, Chanway CP (2000) Influence of millipedes on litter decomposition, $\mathrm{N}$ mineralization, and microbial communities in a coastal forest in British Columbia, Canada. Can J For Res 30:817-826. doi:10.1139/ cjfr-30-5-817

Chong CT, Larned ST, Covich AP, Kinzie III RA (2000) Species interactions between estuarine detritivores: inhibition or facilitation? Hydrobiologia 434:11-16. doi:10.1023/A:1004098425855

Cornelissen JHC, Van Bodegom PM, Aerts R, Callaghan TV, Van Logtestijn RSP, Alatalo J, Chapin FS, Gerdol R, Gudmundsson J, Gwynn-Jones D, Hartley AE, Hik DS, Hofgaard A, Jonsdottir IS, Karlsson S, Klein JA, Laundre J, Magnusson B, Michelsen A, Molau U, Onipchenko VG, Quested HM, Sandvik SM, Schmidt IK, Shaver GR, Solheim B, Soudzilovskaia NA, Stenstrom A, Tolvanen A, Totland O, Wada N, Welker JM, Zhao XQ, The M.O.L. team (2007) Global negative vegetation feedback to climate warming responses of leaf litter decomposition rates in cold biomes. Ecol Lett 10:619-627. doi:10.1111/j.1461-0248. 2007.01051.x

Coûteaux M-M, Bolger T (2000) Interactions between atmospheric $\mathrm{CO}_{2}$ enrichment and soil fauna. Plant Soil 224:123-134. doi: 10.1023/A: 1004685421578

Coûteaux MM, Mousseau M, Celerier ML, Bottner P (1991) Increased atmospheric $\mathrm{CO}_{2}$ and litter quality: decomposition of sweet chestnut leaf litter with animal food webs of different complexities. Oikos 61:54-64

David J-F, Gillon D (2009) Combined effects of elevated temperatures and reduced leaf litter quality on the life-history parameters of a saprophagous macroarthropod. Glob Change Biol 15:156-165. doi:10.1111/j.1365-2486.2008.01711.x

David J-F, Handa IT (2010) The ecology of saprophagous macroarthropods (millipedes, woodlice) in the context of global change. Biol Rev 85:881-895. doi:10.1111/j.1469-185X.2010.00138.x

David J-F, Malet N, Coûteaux M-M, Roy J (2001) Feeding rates of the woodlouse Armadillidium vulgare on herb litters produced at two levels of atmospheric $\mathrm{CO}_{2}$. Oecologia 127:343-349. doi: $10.1007 / \mathrm{s} 004420000599$
De Oliveira T, Hättenschwiler S, Handa IT (2010) Snail and millipede complementarity in decomposing Mediterranean forest leaf litter mixtures. Funct Ecol 24:937-946. doi:10.1111/j.1365-2435. 2010.01694.x

Dorrepaal E, Toet S, Van Logtestijn RSP, Swart E, Van de Weg MJ, Callaghan TV, Aerts R (2009) Carbon respiration from subsurface peat accelerated by climate warming in the subarctic. Nature 460:616-619. doi:10.1038/nature08216

Edwards CA, Bohlen PJ (1996) Biology and ecology of earthworms, 3rd edn. Chapman \& Hall, London

Fierer N, Craine JM, McLauchlan K, Schimel JP (2005) Litter quality and the temperature sensitivity of decomposition. Ecology 86:320-326. doi:10.1890/04-1254

Gessner MO, Swan CM, Dang CK, McKie BG, Bardgett RD, Wall DH, Hättenschwiler S (2010) Diversity meets decomposition. Trends Ecol Evol 25:372-380. doi:10.1016/j.tree.2010.01.010

Hassall M, Turner JG, Rands MRW (1987) Effects of terrestrial isopods on the decomposition of woodland leaf litter. Oecologia 72:597-604. doi:10.1007/BF00378988

Hättenschwiler S, Bretscher D (2001) Isopod effects on decomposition of litter produced under elevated $\mathrm{CO}_{2}, \mathrm{~N}$ deposition and different soil types. Glob Change Biol 7:565-579. doi: 10.1046/j.1365-2486.2001.00402.x

Hättenschwiler S, Bühler S, Körner C (1999) Quality, decomposition and isopod consumption of tree litter produced under elevated $\mathrm{CO}_{2}$. Oikos 85:271-281

Hedde M, Bureau F, Chauvat M, Decaëns T (2010) Patterns and mechanisms responsible for the relationship between the diversity of litter macro-invertebrates and leaf degradation. Basic Appl Ecol 11:35-44. doi:10.1016/j.baae.2009.10.009

Heemsbergen DA, Berg MP, Loreau M, Van Hal JR, Faber JH, Verhoef HA (2004) Biodiversity effects on soil processes explained by interspecific functional dissimilarity. Science 306:1019-1020. doi:10.1126/science. 1101865

Hendriksen NB (1990) Leaf litter selection by detritivore and geophagous earthworms. Biol Fert Soils 10:17-21. doi:10.1007/ BF00336119

Hickling R, Roy DB, Hill JK, Fox R, Thomas CD (2006) The distributions of a wide range of taxonomic groups are expanding polewards. Glob Change Biol 12:45-450. doi:10.1111/j.13652486.2006.01116.x

Hodkinson ID, Wookey PA (1999) Functional ecology of soil organisms in tundra ecosystems: towards the future. Appl Soil Ecol 11:111-126. doi:10.1016/S0929-1393(98)00142-5

Hopkin SP, Read HJ (1992) The biology of millipedes. Oxford University Press, Oxford

IPCC (Intergovernmental Panel on Climate Change) (2007) Climate Change 2007: The physical science basis. Contribution of Working Group I to the Fourth Assessment Report of the Intergovernmental Panel on Climate Change. Cambridge University Press, Cambridge

Jonasson SE, Chapin FS III, Shaver GR (2001) Biogeochemistry in the Arctic: patterns, processes and controls. In: Schulze ED et al (eds) Global biogeochemical cycles in the climate system. Academic Press, San Diego, pp 139-150

Krebs CJ (1999) Ecological methodology, 2nd edn. Addison-Welsey Educational Publishers, Menlo Park

Loreau M, Hector A (2001) Partitioning selection and complementarity in biodiversity experiments. Nature 412:72-76. doi: $10.1038 / 35083573$

Parmesan C, Yohe G (2003) A globally coherent fingerprint of climate change impacts across natural systems. Nature 421:37-42. doi:10.1038/nature01286

Robinson CH (2002) Controls on decomposition and soil nitrogen availability at high latitudes. Plant Soil 242:65-81. doi: 10.1023/A:1019681606112 
Root TL, Price JT, Hall KR, Schneider SH, Rosenzweig C, Pounds JA (2003) Fingerprints of global warming on wild animals and plants. Nature 421:57-60. doi:10.1038/nature01333

Rouifed S, Handa IT, David J-F, Hättenschwiler S (2010) The importance of biotic factors in predicting global change effects on decomposition of temperate forest leaf litter. Oecologia 163:247-256. doi:10.1007/s00442-009-1528-1

Ruess L, Michelsen A, Schmidt IK, Jonasson S (1999) Simulated climate change affecting microorganisms, nematode density and biodiversity in subarctic soils. Plant Soil 212:63-73. doi: 10.1023/A: 1004567816355

Scheu S, Parkinson D (1994) Effects of earthworms on nutrient dynamics, carbon turnover and microorganisms in soils from cool temperate forests of the Canadian Rocky Mountainslaboratory studies. J Appl Soil Ecol 1:113-125. doi:10.1016/ 0929-1393(94)90031-0

Seatre P (1998) Decomposition, microbial community structure, and earthworm effects along a birch-spruce soil gradient. Ecology 79:834-846. doi:10.1890/0012-9658(1998)079

Thomas CD, Bodsworth EJ, Wilson RJ, Simmons AD, Davies ZG, Musche M, Conradt L (2001) Ecological and evolutionary processes at expanding range margins. Nature 411:577-581. doi: $10.1038 / 35079066$

Tian G, Brussaard L, Kang BT (1995) Breakdown of plant residues with contrasting chemical composition under humid tropical conditions: effects of earthworms and millipedes. Soil Biol Biochem 27:277-280. doi:10.1016/0038-0717(94)00182-Z
Tiunov AV, Hale CM, Holdsworth AR, Vsevolodova-Perel TS (2006) Invasion patterns of Lumbricidae into previously earthworm-free areas or northeastern Europe and the western Great Leaks region of North America. Biol Invas 8:1223-1234. doi:10.1007/ s10530-006-9018-4

Trajovský K, Šantrucková H, Hánêl L, Balík V, Lukešová A (1992) Decomposition of faecal pellets of the millipede Glomeris hexasticha (Diplopoda) in forest soil. Pedobiologia 36:146-158

Vos VCA, Van Ruijven J, Berg MP, Peeters ETHM, Berendse F (2011) Macro-detritivore identity drives leaf litter diversity effects. Oikos 120:1092-1098. doi:10.1111/j.1600-0706.2010.18650.x

Warburg MR (1993) Evolutionary biology of land isopods. Springer, Berlin

Wardle DA, Lavelle P (1997) Linkages between soil biota, plant litter quality and decomposition. In: Cadisch G, Giller KE (eds) Driven by nature: plant litter quality and decomposition. CAB International, Oxon, pp 107-124

Wookey PA, Aerts R, Bardgett RD, Baptist F, Bråthen KA, Cornelissen JHC, Gough L, Hartley IP, Hopkins DW, Lavorel S, Shaver GR (2009) Ecosystem feedbacks and cascade processes: understanding their role in the responses of Arctic and alpine ecosystems to environmental change. Glob Change Biol 15:1153-1172. doi:10.1111/j.1365-2486.2008.01801.x

Zimmer M, Kautz G, Topp W (2005) Do woodlice and earthworms interact synergistically in leaf litter decomposition? Funct Ecol 19:7-16. doi:10.1111/j.0269-8463.2005.00926.x 